\title{
Heavy Metals Pollution Level in Water, Fish and Sediments from the Logone River Within Moundou City (Chad)
}

\author{
Massang Tchoroun ${ }^{1}$, Guy Bertrand Noumi ${ }^{1, ~ *, ~ N e w ~ M a h a m a t ~ T c h a d a n a y e ~}{ }^{2}$, \\ Jean Marie Dikdim Dangwang ${ }^{1}$
}

${ }^{1}$ Department of Chemistry, Faculty of Science, University of Ngaoundere, Ngaoundere-Cameroon

${ }^{2}$ Department of Chemistry, Faculty of Science, University of N'Djamena, Chad

\author{
Email address: \\ gnoumi@yahoo.fr (G. B. Noumi), tchorounmassang@yahoo.fr (M. Tchoroun), tchadanaye@gmail.com (N. M. Tchadanaye), \\ ddikdim_jm@yahoo.fr (J. M. D. Dangwang)
}

\section{To cite this article:}

Massang Tchoroun, Guy Bertrand Noumi, New Mahamat Tchadanaye, Jean Marie Dikdim Dangwang. Heavy Metals Pollution Level in Water, Fish and Sediments from the Logone River Within Moundou City (Chad). International Journal of Environmental Monitoring and Analysis. Vol. 3, No. 5, 2015, pp. 275-281. doi: 10.11648/j.ijema.20150305.15

\begin{abstract}
The evaluation of metal pollution level of Logone River at Moundou (Chad) was done by measuring the amount of Iron (Fe), Copper ( $\mathrm{Cu})$, Manganese $(\mathrm{Mn})$, Chromium $(\mathrm{Cr})$, Cadmium $(\mathrm{Cd})$ and lead $(\mathrm{Pb})$. The water, sediments and fish samples were collected around the river at 4 sites and the concentrations were determined by spectrophotometric UV-Visible analyses. The results obtained showed that iron (Fe) had the highest concentration in water with average of $0.77 \pm 0.03 \mathrm{mg} / \mathrm{L}$ followed by $\mathrm{Mn}(0.13 \pm 0.01 \mathrm{mg} / \mathrm{L})$. In contrast, in the sediments $\mathrm{Mn}$ had a highest concentration followed by Fe with an average content of $33.17 \pm 0.04 \mathrm{mg} / \mathrm{kg}$ and $7.61 \pm 0.02 \mathrm{mg} / \mathrm{kg}$ respectively. In both cases, Cd had the lowest concentration of $0.52 \pm 0.03 \mu \mathrm{g} / \mathrm{kg}$ and $0.43 \pm 0.02 \mu \mathrm{g} / \mathrm{L}$ in the sediment and water respectively. The lowest values of enrichment factor $(0-0.88)$ and average contamination indexes ( 0.74 to 0.88 ) indicates that the sediment are not polluted by $\mathrm{As}, \mathrm{Cd}, \mathrm{Cr}$ and $\mathrm{Pb}$. However, $\mathrm{Mn}$ is highly found in sediment with an EF of $76.88 \%$ and $100 \%$ at AM and COT sampling site respectively at which suggest the origin of this heavy metal by Coton tchad activities. The values of bioconcentration factor $(\mathrm{BCF}) \mathrm{of} \mathrm{Cd}, \mathrm{Cr}, \mathrm{Fe}$ and $\mathrm{Mn}$ proved that the fishes are under bioaccumulation step. This study proved that the various waste generated by industries (CotonTchad and Brewery of Chad) and agriculture practices at Moundou affect significantly the quality of Logone River ecosystem.
\end{abstract}

Keywords: Heavy Metals, Pollution, Bioconcentration Factor, Logone River

\section{Introduction}

Generally, the aquatic environment quality is significantly affected by several naturals and anthropic activities [1] which provide many contaminants. However, Heavy metal pollution in aquatic ecosystems is a worldwide environmental problem that has received increasing attention over the last few decades because of its adverse effects [2,3]. The contamination of aquatic systems by heavy metals, especially in sediments, has become one of the most challenging pollution issues owing to the toxicity, abundance, persistence, and subsequent bioaccumulation of these materials [4]. When discharged into aquatic ecosystems, heavy metals can be absorbed by suspended solids, then strongly accumulated in sediments and biomagnified along aquatic food chains [5]. Moreover, these sediments act as sinks, and may in turn act as sources of heavy metals [1]. Thus, heavy metal pollution in aquatic ecosystems has been recently extensively investigated to effectively manage these ecosystems by measuring their concentration in water, sediments and fish [1, 5-12].

Logone River is a largest river in Chad which is use for water drinking, fishing, agriculture etc... Unfortunately, it is affected by the pollution due to multiplication of industrial activities and agricultural practices which are made around. In fact, other than agricultural runoff, this river receive many effluents provide by Coton Tchad and Brewery of Chad located at Moundou. These effluents carry some pollutants (including heavy metals) which lead to affect significantly the quality of the Logone River. Previous works undertake by researchers have focused on the metallic pollution of Lake Chad and Chari River beside Sarh and N'Djamena cities [1011]. In this context, we have investigated this study in order to contribute to understanding the effect of effluent release by industries at Moundou without treatment to the quality of this river.

Therefore, the main objective of this work was to evaluate the heavy metal pollution level in Logone River within Moundou city (Chad) by analyzing water, sediments and fish 
samples by spectrophotometric UV-Visible method and the determination of enrichment factor (EF) and contamination factor $(\mathrm{CF})$.

\section{Materials and Methods}

\subsection{Study Area}

The wide range of Chad's river system is found in the South part of the country. This hydrography is made up of a fluvial network including the Chari and Logone rivers. Resulting from the Vina and Mbere in Cameroon, Logone passes through the town of Moundou in the south of the country. Watered by heavy rainfall reaching $1000 \mathrm{~mm}$ of rain [11] (Figure 1 shows the Map of hydrography in the catchment of the Chari and Logone (TDA / SAP LCBC 2006)), Moundou belongs to a marshy zone with Sudanese climate and dense vegetation. It is located between $08^{\circ} 32^{\prime} 20.1^{\prime \prime}$ and $08^{\circ} 33^{\prime} 11.8^{\prime \prime}$ North latitude and between $16^{\circ} 03^{\prime} 59.3^{\prime \prime}$ and $16^{\circ} 04^{\prime} 45.0^{\prime \prime}$ East longitude. Moundou is renowned for its industries and its strong agglomeration that make it the economic capital of Chad. Despite these challenges, the "Logone River" which goes across the town of Moundou has been no prior academic study.

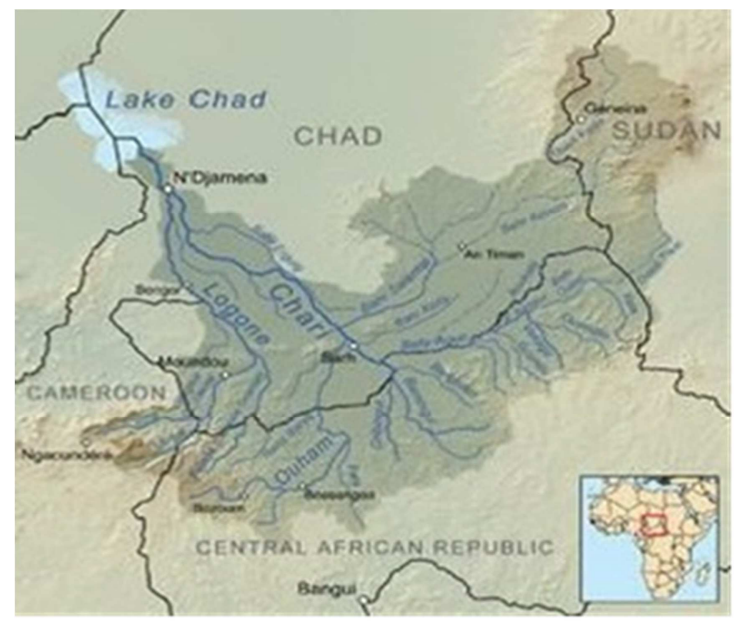

Figure 1. Map of the study area.

\subsection{Samples Collection}

We have identified two major direct discharges of industrial effluents into the study'senvironment. Apart from these points, there was runoff of farm and domestic discharges which were diffuse point source. All these effluents were discharged directly into the Logone River without any treatment. These releases were characterized by specific odors related to each effluent. Based on these activities, four sampling points form upstream and downstream were selected in this study. These sample points were as follows (Figure 2):

- AM: the point located at upstream of the Logone, away from industrial effluents.- COT: sewage effluent discharge from the plant Coton Tchad.

- BRA: sewage effluent discharge Breweries of Chad.

- AVA: point located on downstream factories in the direction of flow of the Logone.

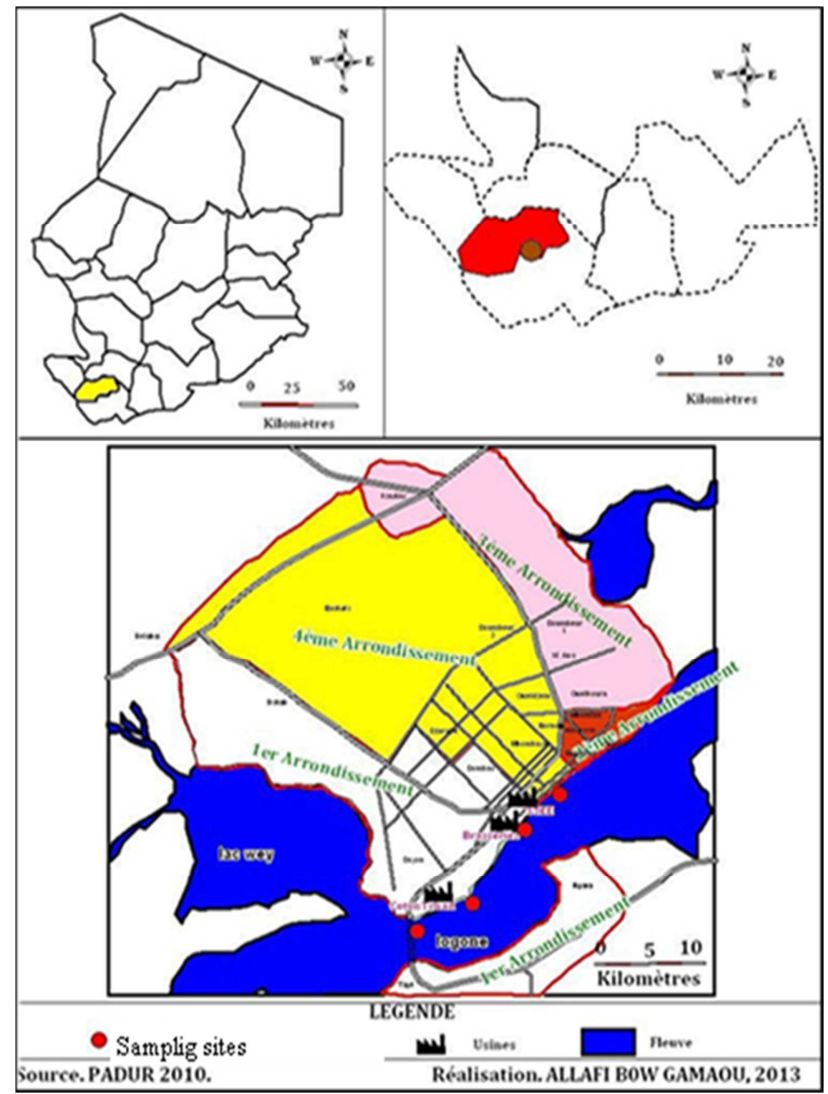

Figure 2. Sampling point location.

The sampling of sediment, fish and water were carried out during a sampling campaign at the beginning of the low water period (November 2014) in the four points.The physico-chemical parameters during this study are given in the Table 1.The fish sampling was achieved at the edge of Logone in Moundou (Chad). The parts of the fish concerned with analyzes were mixture of head, liver and body. The water samples collected in plastic bottles previously washed, rinsed with distilled water and then with water from the Logone River. Each flask was acidified with one drop of $1 \%$ hydrochloric acid and put in the fridge[12].Sediment samples were collected using a polypropylene coring device with 30 $\mathrm{cm}$ long and $25 \mathrm{~cm}$ internal diameter. Typically, cores were comprised of a $5 \mathrm{~cm}$ sediment surface layer for each sample.

Table 1. Physico-chemical parameters of sampling points.

\begin{tabular}{lllll}
\hline & AM & COT & BRA & AVA \\
\hline $\mathrm{pH}$ & $(6.37 \pm 0.01)^{\mathrm{a}}$ & $(6.41 \pm 0.02)^{\mathrm{b}}$ & $(6.46 \pm 0.02)^{\mathrm{b}}$ & $(6.65 \pm 0.02)^{\mathrm{c}}$ \\
$\mathrm{T}\left({ }^{\circ} \mathrm{C}\right)$ & $(27.10 \pm 0.26)^{\mathrm{a}}$ & $(27.70 \pm 0.70)^{\mathrm{b}}$ & $(27.60 \pm 0.26)^{\mathrm{b}}$ & $(28.00 \pm 0.20)^{\mathrm{b}}$ \\
Cond $(\mu \mathrm{S} / \mathrm{cm})$ & $(55.70 \pm 0.40)^{\mathrm{b}}$ & $(57.20 \pm 0.20)^{\mathrm{c}}$ & $(54.60 \pm 0.34)^{\mathrm{a}}$ & $(54.30 \pm 0.30)^{\mathrm{a}}$ \\
Turbidity (NTU) & $(12.30 \pm 0.20)^{\mathrm{b}}$ & $(20.80 \pm 0.40)^{\mathrm{c}}$ & $(20.80 \pm 0.40)^{\mathrm{c}}$ & $(11.90 \pm 0.30)^{\mathrm{a}}$ \\
MIS (mg/L) & $(83.00 \pm 2.64)^{\mathrm{a}}$ & $(94.00 \pm 3.00)^{\mathrm{c}}$ & $(87.00 \pm 1.00)^{\mathrm{b}}$ & $(94.00 \pm 4.00)^{\mathrm{c}}$ \\
\hline
\end{tabular}

$\mathrm{a}, \mathrm{b}, \mathrm{c}, \mathrm{d}$ : in each line, the values affected with the same letter are not significantly different $(\mathrm{p}<0.05)$ 


\subsection{Pretreatment of Samples and Analyses}

Each bottle of water was stirred and $50 \mathrm{ml}$ of the contents were filtered into a $50 \mathrm{~mL}$ flask in which it was previously introduced $0.5 \mathrm{~mL}$ of concentrated hydrochloric acid. The final volume was filtered through a cellulose membrane.

The sediment samples (10 g) were dried, ground and passed through a $125 \mu \mathrm{m}$ mesh sieve. Then pourred into a $100 \mathrm{~mL}$ Erlenmeyer flask containing $50 \mathrm{ml}$ of $1 \mathrm{~N}$ ammonium acetate. The whole was homogenized using a stirrer for 1 hour and filtered through a Whatman paper into a $100 \mathrm{ml}$ flask. The volume was adjusted to $100 \mathrm{~mL}$ using distilled water and finally filtered on a cellulose membrane. Thus, the resulting sample was ready for metal extraction and spectrophotometric analysis.

After extraction, the concentrations of $\mathrm{As}, \mathrm{Cd}, \mathrm{Cr}, \mathrm{Pb}, \mathrm{Mn}$ and $\mathrm{Fe}$ were determined using UV-VIS (HACH DR-2400) spectrophotometer in the Laboratory of Water and Environment (LABEEN) of the University of N'Djamena.

\section{Statistical Analysis}

Data obtained were statistically analyzed by Statgraphic Centurion XV software program using the analysis of variance (ANOVA). Principal component analysis (PCA) was realized using the XLSTAT 2007 software.

\section{Results and Discussion}

\subsection{Heavy Metals in Water}

The analysis of Table 2 showed the following observations.

Table 2. Concentration of heavy metal in water.

\begin{tabular}{llllll}
\hline & AM & COT & BRA & AVA & Standards (mg/L) \\
\hline $\mathrm{Pb}(\mu \mathrm{g} / \mathrm{L})$ & $(0.10 \pm 0.01)^{\mathrm{a}}$ & $(4.33 \pm 0.03)^{\mathrm{d}}$ & $(0.66 \pm 0.05)^{\mathrm{b}}$ & $(2.00 \pm 0.20)^{\mathrm{c}}$ & 0.05 \\
$\mathrm{As}(\mathrm{mg} / \mathrm{L})$ & $(0.17 \pm 0.01)^{\mathrm{c}}$ & $(0.04 \pm 0.01)^{\mathrm{a}}$ & $(0.04 \pm 0.00)^{\mathrm{a}}$ & $(0.13 \pm 0.00)^{\mathrm{b}}$ & 0.05 \\
$\mathrm{Cd}(\mu \mathrm{g} / \mathrm{L})$ & $(0.42 \pm 0.03)^{\mathrm{ab}}$ & $(0.46 \pm 0.01)^{\mathrm{b}}$ & $(0.43 \pm 0.02)^{\mathrm{ab}}$ & $(0.40 \pm 0.02)^{\mathrm{a}}$ & 0.005 \\
$\mathrm{Cr}(\mathrm{mg} / \mathrm{L})$ & $(0.09 \pm 0.01)^{\mathrm{a}}$ & $(0.09 \pm 0.00)^{\mathrm{a}}$ & $(0.10 \pm 0.01)^{\mathrm{a}}$ & $(0.10 \pm 0.00)^{\mathrm{a}}$ & 0.05 \\
$\mathrm{Mn}(\mathrm{mg} / \mathrm{L})$ & $(0.16 \pm 0.01)^{\mathrm{c}}$ & $(0.19 \pm 0.01)^{\mathrm{d}}$ & $(0.08 \pm 0.01)^{\mathrm{a}}$ & $(0.09 \pm 0.01)^{\mathrm{b}}$ & 0.20 \\
$\mathrm{Fe}(\mathrm{mg} / \mathrm{L})$ & $(0.67 \pm 0.03)^{\mathrm{a}}$ & $(0.73 \pm 0.02)^{\mathrm{a}}$ & $(0.84 \pm 0.03)^{\mathrm{b}}$ & $(0.84 \pm 0.04)^{\mathrm{b}}$ & 0.30 \\
\hline
\end{tabular}

$\mathrm{a}, \mathrm{b}, \mathrm{c}, \mathrm{d}$ : in each line, the values affected with the same letter are not significantly different $(\mathrm{p}<0.05)$

Iron: mean concentrations of iron were very high than the other metal with a maximum of $(0.84 \pm 0.04 \mathrm{mg} / \mathrm{L})$ downstream and a minimum of $(0.67 \pm 0.03) \mathrm{mg} / \mathrm{L}$ upstream. The very similar iron contents between points should have probably a soil (or pedological) origin, with a low anthropogenic input.

Lead: the results obtained (Table 2$)$ ranged between $(0.10$ $\pm 0.01) \mu \mathrm{g} / \mathrm{L}$ and $(4.33 \pm 0.03) \mathrm{g} / \mathrm{L}$ with anaverageweight of $(1.77 \pm 0.09) \mu \mathrm{g} / \mathrm{L}$. This lastvalue is lower than the one of the international standard of water quality. The high COT content recorded may be justified by the use of outdated facilities (water pipes) whichdate from the colonial years, and chemical inputs. The recorded content in BRA point was low compared to which obtained COT due to metal recycling facilities (piping INOX) achieved by the breweries of Chad. The presence of Pbat AM point would be a contribution from agriculture by the use of nitrogenous and phosphate fertilizers $[1,13]$.

Chrome: the levels obtained range between $(0.09 \pm 0.00)$ $\mathrm{mg} / \mathrm{L}$ in COTand $(0.10 \pm 0.01) \mathrm{mg} / \mathrm{L}$ in BRA with an average value of $(0.10 \pm 0.01) \mathrm{mg} / \mathrm{L}$. This very small variation between the sampling points could partially be justified by a lack of supply by the plants. Therefore,chromium had origins other than industrials. It may be due to the nature of soils.

Cadmium: concentrations of cadmium ranging from $(0.40$ $\pm 0.02) \mu \mathrm{g} / \mathrm{L}$ (AVA) to $(0.46 \pm 0.04) \mu \mathrm{g} / \mathrm{L}$ (COT) with a mean value of $(0.42 \pm 0.02) \mu \mathrm{g} / \mathrm{L}$. The high content of COT and BRA proved the contribution in $\mathrm{Cd}$ by the two plants as a result to industrial effluents discharged into the Logone. Moderated concentrations encountered in AM and AVA could be carried away by leaching of agricultural soils on which phosphate and potash fertilizers are used [13].The probable sources of $\mathrm{Cd}$ in surface water includes leaching from $\mathrm{Ni}-\mathrm{Cd}$ batteries, run off from agricultural soils where phosphate fertilizers are used and other wastes.

Arsenic concentrations ranged from $(0.04 \pm 0.00) \mathrm{mg} / \mathrm{L}$ (BRA) to $(0.17 \pm 0.00) \mathrm{mg} / \mathrm{L}(\mathrm{AM})$. This high concentration at upstream may be due to the use of phosphate fertilizers, herbicides and insecticides in the fields and orchards. On the other hand, the excess of the downstream value would be the contribution of bleaching by the use of detergents[15]. The average at downstream of $(0.09 \pm 0.00) \mathrm{mg} / \mathrm{L}$, As concentration is 1.89 times greater than the standard value. Nevertheless, this average is still small compared with the critical value (2 mg/L) of triggering toxicity phenomena [14].

Manganese: the contents showed a variation of 0.075 $\mathrm{mg} / \mathrm{L}$ (BRA) to $0.186 \mathrm{mg} / \mathrm{L}$ (COT) for an average of 0.125 $\mathrm{mg} / \mathrm{L}$. The high value of $\mathrm{Mn}$ in COT $(0.186 \mathrm{mg} / \mathrm{L})$ may explain the contribution of Mn by Coton Tchad plant (oil and soap subsidiaries) which deal cottonseeds and then discharges the effluents to the Logone. Indeed, manganese is found mainly in plant debris [14], while the low value recorded in BRA $(0.075 \mathrm{mg} / \mathrm{L})$ assumes that chemical compounds of the brewery effluents contained Mn which was drained by water. The average concentration $(0.155 \mathrm{mg} / \mathrm{L})$ in AM may be justified by the Mn supply by the decomposition of leaves oforchards and forests trees located from upstream of the city [14]. However, this mean remains lower than the results obtained by Opaluwa et al. [7] in Uke Stream (Nigeria) which obtained $0.51 \mathrm{mg} / \mathrm{L}$.

\subsection{Analysis of Heavy Metals in Sediments}

The analysis of Table 3 showed the following observations: 
Manganese: the levels ranged between $(59.51 \pm 0.04)$ $\mathrm{mg} / \mathrm{Kg}$ (COT) and (11.95 \pm 0.05$) \mathrm{mg} / \mathrm{Kg}$ (BRA) for an average weight $(33.17 \pm 0.05) \mathrm{mg} / \mathrm{kg}$; which was low compared to the standard and the results obtained by Opaluwa et al. [7]. Contamination of soils of the Logone river is generalized because the crust naturally contains $1 \%$ $\mathrm{Mn}$. Coton Tchad is the factory that rejects most of Mn in the Logone through its effluents further to the operation of cotton seeds and production of oil. Upstream, the contribution may be due to the use of fertilizers and pesticides by farmers. Previous works have shown that the origin of this element was anthropogenic but also could be natural [15]. The natural occurrence of manganese was confirmed by the works of Biney et al. [16] which showed levels of $750 \mathrm{mg} / \mathrm{Kg}$ for nonpolluted sediments.

Table 3. Concentration of heavy metals in sediment.

\begin{tabular}{|c|c|c|c|c|c|}
\hline & AM & COT & BRA & AVA & Standards (mg/kg) \\
\hline $\mathrm{Pb}(\mu \mathrm{g} / \mathrm{kg})$ & $(66.33 \pm 0.05)^{\mathrm{d}}$ & $(8.33 \pm 0.03)^{\mathrm{a}}$ & $(28.00 \pm 2.00)^{\mathrm{c}}$ & $(12.33 \pm 0.03)^{\mathrm{b}}$ & 100 \\
\hline As $(\mathrm{mg} / \mathrm{kg})$ & $(0.09 \pm 0.00)^{\mathrm{a}}$ & $(0.15 \pm 0.00)^{\mathrm{c}}$ & $(0.16 \pm 0.00)^{\mathrm{d}}$ & $(0.12 \pm 0.01)^{\mathrm{b}}$ & 14 \\
\hline $\mathrm{Cd}(\mu \mathrm{g} / \mathrm{kg})$ & $(0.45 \pm 0.04)^{\mathrm{a}}$ & $(0.42 \pm 0.01)^{\mathrm{a}}$ & $(0.44 \pm 0.03)^{\mathrm{a}}$ & $(0.75 \pm 0.02)^{b}$ & 2 \\
\hline $\mathrm{Cr}(\mathrm{mg} / \mathrm{kg})$ & $(0.53 \pm 0.05)^{c}$ & $(0.34 \pm 0.01)^{\mathrm{b}}$ & $(0.13 \pm 0.02)^{\mathrm{a}}$ & $(0.40 \pm 0.05)^{\mathrm{b}}$ & 150 \\
\hline $\mathrm{Mn}(\mathrm{mg} / \mathrm{kg})$ & $(45.75 \pm 0.05)^{\mathrm{c}}$ & $(59.51 \pm 0.01)^{\mathrm{d}}$ & $(11.95 \pm 0.05)^{\mathrm{a}}$ & $(15.48 \pm 0.04)^{b}$ & - \\
\hline $\mathrm{Fe}(\mathrm{mg} / \mathrm{kg})$ & $(8.56 \pm 0.00)^{c}$ & $(6.32 \pm 0.04)^{b}$ & $(11.76 \pm 0.04)^{\mathrm{d}}$ & $(2.85 \pm 0.02)^{\mathrm{a}}$ & - \\
\hline
\end{tabular}

$\mathrm{a}, \mathrm{b}, \mathrm{c}, \mathrm{d}$ : in each line, the values affected with the same letter are not significantly different $(\mathrm{p}<0.05)$

Arsenic: the results oscillated between $(0.161 \pm 0.00)$ $\mathrm{mg} / \mathrm{Kg}(\mathrm{BRA})$ and $(0.094 \pm 0.00) \mathrm{mg} / \mathrm{Kg}(\mathrm{AM})$ with a mean of $(0.13 \pm 0.00) \mathrm{mg} / \mathrm{kg}$; probably, the pollution by industrial effluents and wastes. Nevertheless, high levels found in AM and AVA could be due to the use of phosphate fertilizers, herbicides and insecticides on one hand, and detergents in washing stations on the other. Although significant, the pollution of soil by arsenic was less marked than that observed in other ecosystems. While the works of Helle et al. [17] in Hanoï (Vietnam) showed average values of 39.77 $\mathrm{mg} / \mathrm{kg}$ and $32.33 \mathrm{mg} / \mathrm{kg}$ in To Lich and Kim Nguu rivers respectively.

Cadmium: Results varied from $(0.75 \pm 0.02) \mu \mathrm{g} / \mathrm{Kg}$ in AVA to $(0.42 \pm 0.01) \mathrm{mg} / \mathrm{kg}$ in COT with a mean of 0.51 $\mathrm{mg} / \mathrm{kg}$. These contents obtained were very low compared to the results of Opaluwa et al.[7] in Uke stream $(35 \mathrm{mg} / \mathrm{kg})$. Other results were found $1.75 \mathrm{mg} / \mathrm{kg}$ in Kim Nguu River (Vietnam) and $70.14 \mathrm{mg} / \mathrm{kg}$ in To Lich River in Hanoi [17].

Chromium: the levels were between $(0.13 \pm 0.02) \mathrm{mg} / \mathrm{Kg}$ (BRA) and $(0.53 \pm 0.05) \mathrm{mg} / \mathrm{Kg}(\mathrm{AM})$ with an average value of $(0.35 \pm 0,03) \mathrm{mg} / \mathrm{kg}$. Indeed, the levels determined were negligible compared to the European standard. A study carried out by Helle et al.[17] obtained a mean of $171 \mathrm{mg} / \mathrm{kg}$ in To Lich River and $169.5 \mathrm{mg} / \mathrm{kg}$ in Kim Nguu River in Hanoi(Vietnam). Sieliechi et al. [1] found $142.87 \mathrm{mg} / \mathrm{Kg}$ in Lake Dang (Cameroon) and these difference may be due to the nature of surface water (static compared to dynamic system). The comparison of results of the current study with other and those of the French Agencyof standardization confirmed that the Logone River was not polluted by chromium. As a matter of fact, minimum contentsrecorded may havea geological origin relating to the soil type.

Lead: the results were from $(08.33 \pm 0.03) \mu \mathrm{g} / \mathrm{Kg}(\mathrm{COT})$ to $(66.33 \pm 0.05) \mu \mathrm{g} / \mathrm{Kg}(\mathrm{AM})$ with an average of $(28.74 \pm$ $0.53) \mu \mathrm{g} / \mathrm{kg}$. This meanwas widely tolerated compared to the European standard (AFNOR NFU 44-041). However, the content determined at the brewery could be provided by reagents and products used for beer brews whereas upstream the levels might be due to the natural supply from the soil.

Iron: the results emerged from this work range from $(2.85$ $\pm 0.02) \mathrm{mg} / \mathrm{Kg}$ (AVA) to $(11.76 \pm 0.04) \mathrm{mg} / \mathrm{Kg}$ (BRA) for an average of $(7.37 \pm 0.03) \mathrm{mg} / \mathrm{kg}$. This excludes the use of the term "pollution". Therefore, the results showed that soils were naturally poor in iron and that iron inputs byfactories were negligible. However, breweries still contribute to the increased concentrations of iron from raw materials and reagents used.

\subsection{Analysis of Heavy Metals in Fish}

The analysis of Table 4 showed the following observations.

Table 4. Concentration of heavy metals in fish sample.

\begin{tabular}{lll}
\hline & Concentration & Standards \\
\hline $\mathrm{As}(\mathrm{mg} / \mathrm{kg})$ & $0.08 \pm 0.00$ & - \\
$\mathrm{Cd}(\mu \mathrm{g} / \mathrm{kg})$ & $0.47 \pm 0.00$ & $2 \mathrm{mg} / \mathrm{kg}$ \\
$\mathrm{Cr}(\mathrm{mg} / \mathrm{kg})$ & $0.19 \pm 0.00$ & $150 \mathrm{mg} / \mathrm{kg}(\mathrm{FAO}, \mathrm{OMS})$ \\
$\mathrm{Pb}(\mathrm{mg} / \mathrm{kg})$ & $1.00 \pm 0.20$ & $2 \mathrm{mg} / \mathrm{kg}$ \\
$\mathrm{Mn}(\mathrm{mg} / \mathrm{kg})$ & $16.80 \pm 0.80$ & - \\
$\mathrm{Fe}(\mathrm{mg} / \mathrm{kg})$ & $6.52 \pm 0.00$ & $7 \mathrm{mg} / \mathrm{kg}$ \\
\hline
\end{tabular}

Manganese: Mn concentrated in fish was due to the consumption of phytoplankton contaminated soil, mud and water. The $\mathrm{Mn}$ content $(16.80 \pm 0.80) \mathrm{mg} / \mathrm{kg}$ remains high compared to continental data compilated by Biney et al.[16] during the survey conducted by FAO. We noted that the levels were irregularly distributed $(1.00 \pm 0.20 \mathrm{mg} / \mathrm{kg})$ in fish in inland waters. This result exceeded most of the results obtained by other authors $(0.66 \mathrm{mg} / \mathrm{g}$ for Clariasgaripienus obtained by Opaluwa et al.[7] and (0.08) $\mu \mathrm{g} / \mathrm{kg}$ for Tilapia nilotica obtained by Elnimr [6]) but not yet be alarming.

Arsenic: The As content was due to the consumption of lower plant organisms, water and mud of the site. The value obtained in this study was $(0.08 \pm 0.00) \mathrm{mg} / \mathrm{kg}$. It was low compared to those found in other fish water bodies. For example: $0.36 \mathrm{mg} / \mathrm{Kg}$ and $0.28 \mathrm{mg} / \mathrm{kg}$ in Nakurulake and Mcllwaine lake in Kenya and Zimbabwe respectively [18]. However, the results obtained were consistent with the range defined by the tolerance threshold.

Cadmium: the result obtained $(0.47 \mu \mathrm{g} / \mathrm{kg})$ was below the WHO threshold $(7 \mathrm{mg} / \mathrm{kg})$. The content was higher than the concentrations observed in Tilapia Nilotica $(0.12 \mu \mathrm{g} / \mathrm{g})$ and 
Pangasius hypothalmus $(0.12 \mu \mathrm{g} / \mathrm{g})$ fishes obtained by Elnimr [6] and these obtained by Opaluwa et al.[7] for Clarias garipienus $(0.047 \mu \mathrm{g} / \mathrm{kg})$. This rate could be due to bioaccumulation of levels contained in water and plankton present in the medium.

Chrome: the result observed on this study $(0.19 \mathrm{mg} / \mathrm{kg})$ was very low compared with the admitted limit $(150 \mathrm{mg} / \mathrm{kg}$ of fresh weight) established by FAO/WHO and EVM (Expert Group on Vitamins and Minerals) [18]. This result was higher to which obtained by Karakus et al.[19] (ranged from 0.0053 to $0.0140 \mathrm{mg} / \mathrm{kg}$ ) in the Karsriver in Turkey. Yet,it was comparable to the concentrations (from 0.03 to 0.39 $\mathrm{mg} / \mathrm{kg}$ ) recorded forthe five fish species by El Morhit et al.[20] in the estuary of the Loukkos River (Morocco). According to the same author, similar values were reported in muscles of Lisa aurata $(0.029-0.038 \mathrm{mg} / \mathrm{kg})$, Solea vulgaris (0.045-0.033 mg/kg )and Anguilla anguilla ( 0.143-0.368 $\mathrm{mg} / \mathrm{kg}$ ) of the South Atlantic coast of Spain.

Lead: It's a toxic metal and its presence over the norm caused the poisoning and damage of aquatic flora. The $\mathrm{Pb}$ rate obtained was very low compared to the WHO standard $(2.0 \mathrm{mg} / \mathrm{g})$. Furthermore, it was lower compared to results obtained by Elnimr [6] on Tilapia Nilotica $(1.51 \mathrm{mg} / \mathrm{kg})$.

Iron: the result recorded $(6.52 \pm 0.00 \mathrm{mg} / \mathrm{Kg})$ was within the range of Africandataandbelow the WHO threshold (7 $\mathrm{mg} / \mathrm{kg}$ ). The iron in soil and water concentrated in fish transferringby planktons. Our value is very low compared to result obtained by Opaluwa et al. [7] on Clarias garipienus $(0.54 \mathrm{mg} / \mathrm{g})$. There were also some doses which were lower: $5.4 \mathrm{mg} / \mathrm{kg}$ in the Niger Delta in Nigeria [22].

\subsection{Assessment of Contamination Degree of Sediments}

\subsubsection{Ic and Im Contamination Indexes}

The assessment of pollution, through the only determination of metal concentrations in sediments, is not an obvious approach which needs to be completed. Thus, Belamie et al.[22] expressed metal contamination using the index of contamination Ic (content of the metal/reference content) and average contamination index Im.

$\mathrm{Im}=\Sigma \mathrm{Ic} \mathrm{n}$; withn the number of samples analyzed.

Based on the results in table 5, these indexes were relatively low for all metals analyzed. Our results were lower compared with those obtained by Hamid et al.[23] in sediments of Tislit-Talsint Wadi in eastern Morocco.Ending, the Logone sediments were not contaminated because $\operatorname{Im}<2$ at all sampling points.

Table 5. Ic and Im indexes for sediments.

\begin{tabular}{llllllll}
\hline & Ic & & & & & & \multirow{2}{*}{ Im } \\
\cline { 2 - 6 } & $\mathbf{A s}$ & $\mathbf{P b}$ & $\mathbf{C d}$ & $\mathbf{C r}$ & $\mathbf{F e}$ & $\mathbf{M n}$ & \\
\hline AM & 1.00 & 1.00 & 1.00 & 1.00 & 1.00 & 1.00 & 1.00 \\
COT & 1.58 & 0.13 & 0.93 & 0.64 & 0.73 & 1.3 & 0.88 \\
BRA & 1.71 & 0.43 & 0.97 & 0.24 & 1.37 & 0.26 & 0.83 \\
AVA & 1.23 & 0.19 & 1.66 & 0.75 & 0.33 & 0.33 & 0.74 \\
\hline
\end{tabular}

\subsubsection{Enrichment Factors}

Enrichment factor (EF) can be used to differentiate between the metals originating from anthropogenic activities and those from natural procedure, and to assess the degree of anthropogenic influence. The enrichment factor (Table 6) varied between $0.00(\mathrm{Cd})$ and $100.00(\mathrm{Mn})$ in TOC. It was null for cadmium in any sampled points: there was no cadmium enrichment in Logone. In contrast, there wasstrong manganese enrichment TOC (100\%) and AM (76.87\%): the majority of Mn was trapped in the soil. For the same element we found that the enrichment factor varied from one point to anotherrandomly.

Table 6. Enrichment factor values.

\begin{tabular}{lllllll}
\hline & EF (\%) & & & & & \\
\cline { 2 - 7 } & As & Pb & Cd & Cr & Fe & Mn \\
\hline AM & 0.15 & 0.11 & 0 & 0.88 & 14.38 & 76.87 \\
COT & 0.25 & 0.01 & 0 & 0.57 & 10.62 & 100.00 \\
BRA & 0.27 & 0.05 & 0 & 0.22 & 19.76 & 20.08 \\
AVA & 0.19 & 0.02 & 0 & 0.67 & 4.82 & 26.01 \\
\hline
\end{tabular}

\subsection{Bioconcentration Factor (BCF) of Heavy Metals by Fish}

Based on results expressed in table $7 \mathrm{BCF}$ values can be divided into three groups. For the first group, the BCF was less than 1 (arsenic and lead). The second group contained values between 2 and 10: these were chromium and iron. The last group was the manganese $(\mathrm{BCF}=140)$. Bioaccumulation phenomenon begins weakly on cadmium to be strong on manganese.

Table 7. Bioconcentration factor (BCF) values.

\begin{tabular}{|c|c|c|c|c|c|c|}
\hline & As & $\mathbf{P b}$ & Cd & $\mathrm{Cr}$ & $\mathbf{F e}$ & Mn \\
\hline $\begin{array}{l}\text { Concentration in } \\
\text { water }(\mathrm{mg} / \mathrm{L})\end{array}$ & 0.09 & $1.99 .10^{-3}$ & $4.27 .10^{-4}$ & 0.09 & 0.77 & 0.12 \\
\hline $\begin{array}{l}\text { Concentration in } \\
\text { fish }(\mathrm{mg} / \mathrm{kg})\end{array}$ & 0.08 & $9.95 \cdot 10^{-4}$ & $0.47 .10^{-3}$ & 0.19 & 6.52 & 16.80 \\
\hline $\mathrm{BCF}$ & 0.89 & 0.50 & 1.10 & 2.00 & 8.46 & 140.00 \\
\hline
\end{tabular}

\subsection{Principal Components Analysis (PCA)}

\subsubsection{Analysis Water Samples}

Table 8. Correlations between metals in water and axes.

\begin{tabular}{lll}
\hline & F1 & F2 \\
\hline $\mathrm{Pb}$ & 0.692 & -0.442 \\
$\mathrm{Cd}$ & 0.778 & -0.572 \\
$\mathrm{Cr}$ & -0.954 & -0.315 \\
$\mathrm{Fe}$ & -0.811 & -0.554 \\
$\mathrm{Mn}$ & 0.989 & 0.130 \\
$\mathrm{As}$ & -0.129 & 0.963 \\
\hline
\end{tabular}

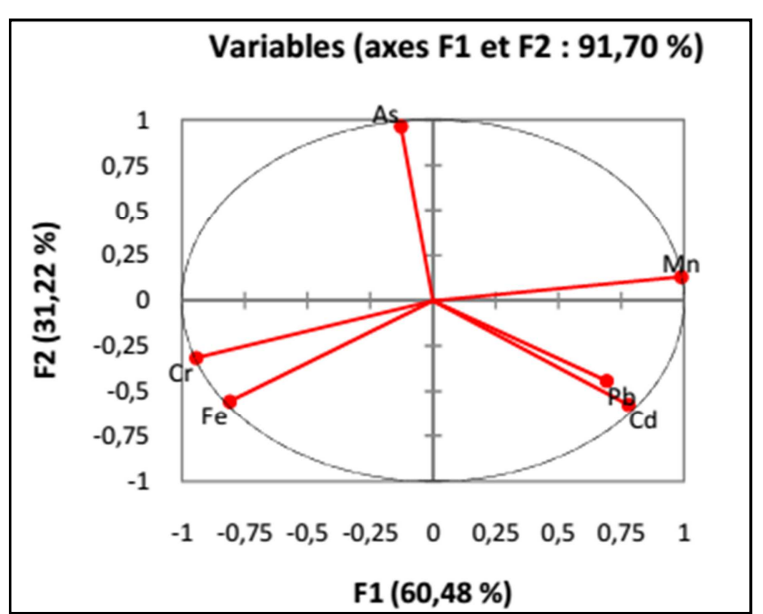

Figure 3. Correlation circle (F1 vs. F2) obtained for heavy metal in water. 
The two main components (F1 and F2) were considered in this analysis, with a total variance of $91.70 \%$. The variables were well represented in this factorial design since the F1 axis divided metals into two opposing groups: group1 included $\mathrm{Cr}, \mathrm{Fe}, \mathrm{Pb}, \mathrm{Cd}$ while Group 2 includedAs and $\mathrm{Mn}$. The F2axis opposed As, Cr and Fe for the first group while $\mathrm{Mn}, \mathrm{Cd}$ and $\mathrm{Pb}$ made the second group (Figure 3 ).

These results showed that $\mathrm{Cr}$ and $\mathrm{Fe}$ in the one hand, $\mathrm{Pb}$ and $\mathrm{Cd}$ were provided in the logone River by the same source of pollution.

\subsubsection{Analysis of Sediments Samples}

The two main components (F1 and F2) were considered in this analysis, with a total variance of $80.57 \%$. The variables were well represented in this factorial layout since F1 and F2 axes divided metals into two opposing groups: the group of $\mathrm{Mn}, \mathrm{Pb}, \mathrm{Cr}$ andCd, with the oneof Asand Fe(Figure 4).

Table 9. Correlations between heavy metals in sediments and axes.

\begin{tabular}{lll}
\hline & F1 & F2 \\
\hline $\mathrm{As}$ & -0.948 & 0.172 \\
$\mathrm{Cr}$ & 0.971 & -0.212 \\
$\mathrm{Mn}$ & 0.305 & -0.537 \\
$\mathrm{Fe}$ & -0.641 & -0.686 \\
$\mathrm{~Pb}$ & 0.372 & -0.772 \\
$\mathrm{Cd}$ & 0.447 & 0.851 \\
\hline
\end{tabular}

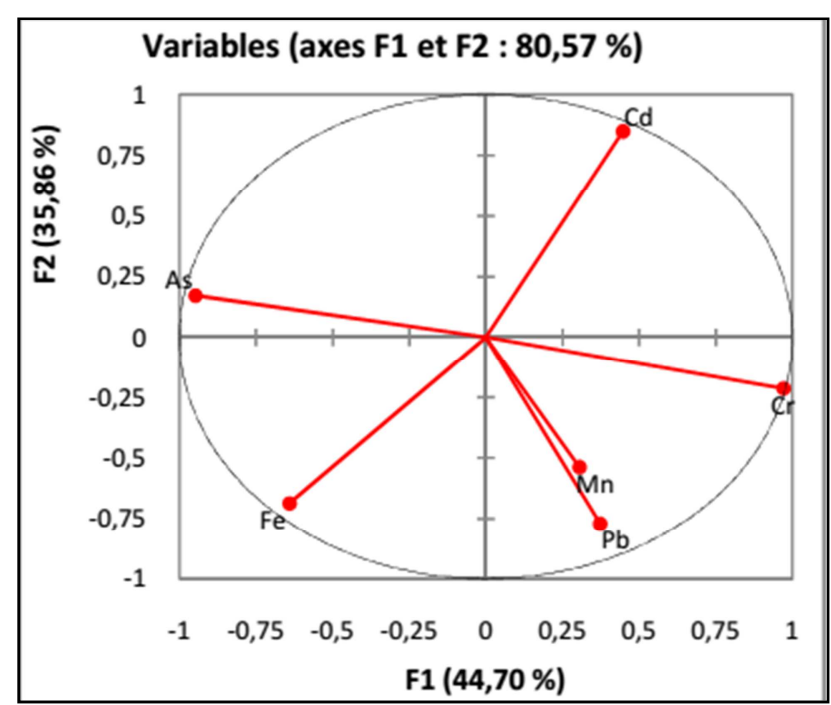

Figure 4. Correlation circle (F1 vs. F2) obtained for heavy metal in sediments.

These results suggest that the heavy metals were distributed randomly in the sediment of Logone River, but $\mathrm{Mn}$ and $\mathrm{Pb}$ were provided by the same source of pollution.

\section{Conclusion}

This research has led to a diagnosis of metal contamination of the portion of the Logone River at Moundou in Chad. The doses recordedat all were below international standards. Duringthe researchwe found that high levels of $\mathrm{Pb}, \mathrm{Cr}$ and $\mathrm{Fe}$ occurredat upstream which excludes the hypothesis that the contaminationin logone had only industrial origin. Regarding water, some elements had levels higher than the standards. These were: $\mathrm{Cr}(0.095 \mathrm{mg} / \mathrm{L}), \mathrm{Mn}(0.125 \mathrm{mg} / \mathrm{L})$, As $(0.094$ $\mathrm{mg} / \mathrm{L})$ and $\mathrm{Fe}(0.77 \mathrm{mg} / \mathrm{L})$. While other had lower levels: $\mathrm{Pb}$
(1.99 $\mu \mathrm{g} / \mathrm{L})$ and $\mathrm{Cd}(0.43 \mu \mathrm{G} / \mathrm{L})$. For fish samples, BCF factors were greater than 1 for elements such as $\mathrm{Cd}(\mathrm{BCF}=$ $1.1), \mathrm{Cr}(\mathrm{BCF}=2), \mathrm{Fe}(\mathrm{BCF}=8.46)$ and $\mathrm{Mn}(\mathrm{BCF}=140)$; indicating a bioconcentrationin the fish. This study showed that the Logone River is relatively polluted by heavy metals and industries affect significantly his water quality.

\section{References}

[1] Sieliechi, J. M., Noumi, G. B., Fadimatou, M., Ali, A. and Kapseu, C., 2013, Speciation of heavy metals in sediments sampled from different pollution sources of Lake Dang, Ngaoundere-Cameroon. International Journal of Environment Protection 2(3), 10-19.

[2] Ma, Z., Chen, K., Yuan, Z., Bi, J. and Huang, L., 2013, Ecological risk assessment of heavy metals in surface sediments of six major Chinese freshwater lakes. Journal of Environment Quality, 42, 341-350.

[3] Wang, Y. M., Kinraide, T. B., Wang, P., Zhou, D. M. and Hao, X. Z., 2013, Modeling rhizotoxicity and uptake of $\mathrm{Zn}$ and Co singly and in binary mixture in wheat in terms of the cell membrane surface electrical potential. Environmental Science and Technology47, 2831-2838.

[4] Barlas, N., Akbulut N. and Aydogan, M., 2005, Assessment of heavy metal residues in the sediment and water samples of Uluabat Lake, Turkey. Bulletin of Environmental Contamination and Toxicology74, 286-293.

[5] Yi, Y., Yang, Z. and Zhang, S., 2011, Ecological risk assessment of heavy metals in sediment and human health risk assessment of heavy metals in fishes in the middle and lower reaches of the Yangtze River basin. Environmental Pollution159, 2575-2585.

[6] Elnimr, T., 2011, Evaluation of some heavy metals in Pangasiushypothalmus and Tilapia nilotica and the role of acetic acid in lowering their levels. International Journal of Fisheries and Aquaculture 3(8), 151-157.

[7] Opaluwa, O. D., Aremu, M. O., Ogbo, L. O., Magaji, J. I., Odiba, I. E. and Ekpo, E. R., 2012, Assessment of Heavy Metals in Water, Fish and Sediments from UKE Stream, Nasarawa State, Nigeria. Current World Environment 7(2), 213-220.

[8] Uwah, I. E., Solomon, F. D., Rebecca, A. E. and Unyime, E. U., 2013, Evaluation of Status of Heavy Metals Pollution of Sediments in Qua-Iboe River Estuary and Associated Creeks, South-Eastern Nigeria. Environment and Pollution 2(4), 110-122.

[9] Obaidy, M. J. A. H., Adel, H. T. and Shahad, R. Z., 2014, Environmental Assessment of Heavy Metal Distribution in Sediments of Tigris River within Baghdad City. International Journal of Advanced Research 2(8), 947-952.

[10] Kayalto, B., 2009, Contribution à l'évaluation de la contamination par les métaux lourds des trois espèces de poissons, des sédiments et des eaux du Lac Tchad. Mémoire de DEA, Université de Ngaoundéré.

[11] Ngaram, N., 2011, Contribution à l'étude analytique des polluants (en particulier de type métaux lourds) dans les eaux du fleuve Chari lors de sa traversée de la ville de N'Djamena, Thèse de Doctorat, Université de N'Djamena.

[12] Chale, M. M., 2002, Trace metal concentrations in water, sediment and fish tissue from Lake Tanganika. The Science of the Total Environment299, 115-121. 
[13] Muhlbaier, J. and Tisue, G. T., 1981, Cadmium in southern bassin Lake Michigan. Water, Air and Soil Pollution15, 45-49.

[14] Rodier, J., Bernard, L. and Merlet, N., 2009, L'analyse de l'eau 9 édition. (France: Dunod press) $1600 \mathrm{p}$.

[15] Ouzair, A., Lebkiri, A., Belghyti, D., Fadli, M., Rifi, E., Hbaiz, E., Ouihman, E., and Lebkiri, M., 2011, Etude Typologique de la contamination métallique du sédiment et caractéristiques physico-chimiques de l'eau d'oued Rdoum (Maroc)». Catégorie, Environnement, ScienceLib Editions Mersenne: 3, $\mathrm{N}^{\circ} 11040,2111-4706$.

[16] Biney, C. A., Calamari, D., Naeve, H., Maembe, T.W., Nyakageni, B., and Saad, M.A.H., 1994, Scientific basis for pollution control. FAO (CIFA) Technical Paper 25, 7-20.

[17] Helle, M., Anders, D. and Peter, E.H., 2008, Content, distribution and fate of 33 elements in sediment of rivers receiving wastewater in Hanoï, Vietnam. Environmental Pollution 155, 41-51.

[18] Greichus, Y. A., 1978, Insecticides, polychlorinated biphenylsand metals in African lake ecosystems2. Lake McIlwaine, Rhodesia. Bulletin of Environmental Contamination and Toxicology19, 44-53.
[19] Karakus, S. and Gey, H., 2006, A preliminary study of heavy metals in transcaucasian barb (Capoetacapoetacapoeta Guldenstaedt, 1772) from the Kars Creek, Turkey. Review of Veterinary Medicine, 157(11), 551-556.

[20] M. El Mohrit, 2012, Metallic contamination of Anguila Anguila at the estuary of Loukkos. In: $3^{\text {th }}$ congress FrancoMagrebian of Zoology and Ichtyology. Morocco, pp 14.

[21] Kakulu, S. E. and Osibanjo, O., 1988, Trace heavy metal pollution studies in sediments of the Niger delta area of Nigeria. Journal of the Chemical Society of Nigeria 13, 9-15.

[22] Belamie R. and Phelippot, S., 1982, Division Qualité des Eaux, Pèche et pisciculture; Rap. $\mathrm{N}^{\circ} 16$

[23] Hamid, T., Ben, S., Ahmed, Hajjaji, N. and Srhiri, A., 2011, Contribution of the evaluation of metals pollution of sediments of the river Tislit-Talsint, watershed guir (Eastern Morocco). ScienceLib Editions Mersenne: volume 3, $\mathrm{N}^{\circ} 111109$. 